\title{
Hubert Horace Lamb (1913-97)
}

\section{Climatologist who pioneered the study of climate change}

Given the worries about the threat to climate posed by anthropogenic emissions of greenhouse gases, it is all too easy to forget that, until the 1970s, the meteorological establishment refused to recognize the inconstancy of climate on timescales of decades and centuries. For much of the twentieth century, atmospheric scientists considered climatology to be a rather dull, bookkeeping exercise, and the study of climate change a fringe science.

Hubert 'H. H.' Lamb, who died on 28 June aged 83, did more than any other modern-day climatologist to change this state of affairs - he was among the first to alert the scientific community to the natural vagaries of climate over recent centuries and millennia, and to point to their possible effects on human societies.

Lamb came from a family that already had a distinguished scientific record. His grandfather, Horace Lamb, was a famous mathematician, author of textbooks widely used by meteorologists. His father was a professor of engineering. One aunt was a tutor at Newnham College, another lectured in archaeology. The young Lamb favoured history and languages at Oundle school, Northamptonshire, but was forced to abandon these subjects in favour of science because, as he later described it, of the "terrible concentration of expectations" placed upon him by his father.

But he rebelled. Starting his undergraduate career in natural sciences at the University of Cambridge, he defied his father and ended in geography. This experience of a catholic range of subjects at the secondary and tertiary levels of education provided a strong underpinning for the interdisciplinary nature of his later work.

Rebellion in the face of parental pressure, later to evolve into a propensity to question conventional scientific wisdom, became allied to a strong belief in the social responsibility of science and of individual scientists. This belief was fostered by discussions with Trevor Huddleston, a family friend who was later to become a prominent critic of apartheid, and Lewis Fry Richardson, a Quaker and a pioneer of numerical weather forecasting.

Lamb's career with the Meteorological Office, which he joined in 1936, almost came to an early end when he was asked to

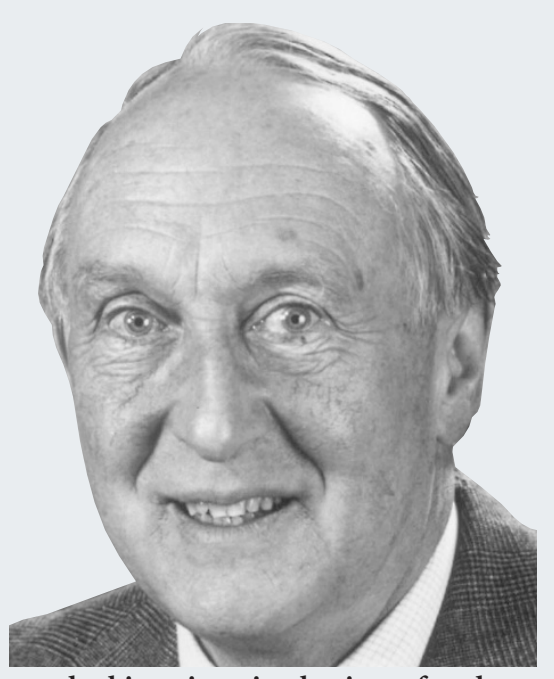

tender his resignation having refused to accept an instruction to work on the meteorology of gas spraying during the war years. In the event, he was transferred to the Irish Meteorological Office where his main responsibility was forecasting for the new trans-Atlantic passenger flights. In 1945 , Lamb resigned from this post after disagreeing with the director over the effect of increasing workloads on aircraft safety, and rejoined the British Meteorological Office the following year.

Working with limited weather data in Ireland during the war (when neutral Ireland was not allowed access to observations made from the United Kingdom) stood him in good stead during the late 1940s when he headed south to the Antarctic as expedition meteorologist on the whaler Balaena. It was during this time that Lamb, on the basis of his own observations in southern waters, began to doubt that climate was quite as constant as generally believed. His transfer to the climatology department of the Meteorological Office in 1954 proved a turning point. Lamb now began to establish an international reputation as a scientist able to cross disciplinary boundaries freely, making use of fragmentary data to weave a rich story of climate change and its effects on human affairs.

During the 1950s and 1960s, increasing contacts with interdisciplinary pioneers in the fields of history, botany and geology, amongst others, provided a basis for his most significant contribution to modern climatology, his two-volume treatise, Climate: Present, Past and Future (Methuen), which eventually appeared during the 1970s. Taking advantage of the extensive archives at the Meteorological Office, Lamb also produced a series of shorter works on past variations in climate and the atmospheric circulation, their causes and effects on humanity, that have provided a lasting inspiration to later generations of researchers. It is, perhaps, as a source of modest and unassuming inspiration to scholars of climatic variation that $\mathrm{H}$. H. Lamb will be best remembered.

In 1963, Lamb had been awarded a special merit promotion in recognition of his work on Antarctica and thus had the freedom to pursue his own research interests. But by the end of the 1960s even that arrangement proved insufficient to support his research ambitions. In 1971, he left the Meteorological Office and established the Climatic Research Unit at the University of East Anglia as a base for interdisciplinary work on climate change. He was director of the unit for six years, before retiring, and again broke new ground by creating a research group entirely funded by external grants and contracts; now, a quarter of a century later, the unit is recognized as a world authority not only on natural climate variability but also anthropogenic change. During this period, he also established a public presence, becoming the person the media turned to during flood or drought, heatwave or blizzard, thereby establishing a broader awareness of the vagaries of climate outside the scientific community.

After retirement, Lamb published two editions of his highly regarded account of climate and human affairs, Climate, History and the Modern World, also with Methuen. He was awarded the Symons Gold Medal by the Royal Meteorological Society in 1987 and completed his autobiography shortly before his death.

During his later years, Lamb was sceptical of certain claims regarding the dangers posed by global warming. An empiricist at heart, and well aware of the complexities of the climate system, he felt that climate models were limited in their ability to provide accurate forecasts. As he observed in 1994, "there has been too much theory and not enough fact in predicting the future". He had found a new orthodoxy to challenge.

Yet Lamb, as much as any scientist, prepared the ground for the research on anthropogenic climate change, and the public and political acceptance of the threat, that would, in 1992, result in the United Nations Framework Convention on Climate Change - the international community's initial response to this pressing environmental problem.

\section{Mick Kelly}

Mick Kelly is in the Climatic Research Unit, University of East Anglia, Norwich NR4 7TJ, UK. e-mail:m.kelly@uea.ac.uk 